\title{
Saints across Traditions and Time Periods: Methods for Increasing Range and Reading in Comparative Frameworks
}

\author{
Todd E. French
}

Department of Philosophy and Religion, Rollins College, 1000 Holt Ave., Winter Park, FL 32789, USA; tfrench@rollins.edu

Received: 19 September 2019; Accepted: 11 October 2019; Published: 16 October 2019

\begin{abstract}
This paper offers a nascent attempt at best practices for the comparative method in a conference setting. Exploring the value in transcendence of traditions and specialization, it traces the preparation and outcome of a recent comparative hagiology panel and develops a list of possible steps for facilitating meaningful interchange between scholars. Building on Freiberger's methodology for Comparative Religions, it applies a method specifically to hagiographical studies.
\end{abstract}

Keywords: collaborative scholarship; comparative method; Comparative Religions; disciplinary innovation hagiography; hagiology; Religious Studies; Sainthood; sacred biography

\section{Introduction}

A recent, popular text by David Epstein, titled Range, argues for the necessity of rethinking our current models of specialization. ${ }^{1}$ In it Epstein explores numerous areas that have benefited from the hand of a generalist, or at least someone who could see beyond their tightly-focused specialization. It seems that the interest in breadth, as well as depth, is returning to favor in the popular and scholarly contexts. Building on the work of Oliver Freiberger and his notion of the "illuminative" nature of comparative work, this paper will explore some areas of growth that are available specifically to the scholars willing to transcend their traditional boundaries. From there, it will apply Freiberger's methodology for comparative studies to a more specific framework of hagiography, in the context of a 2018 conference panel. ${ }^{2}$ From my perspective, Hagiology, and indeed the study of Religion has experienced stunted growth due to its own reliance on specialization. While exceptions are proliferating, there are compelling reasons for this historically being the case. ${ }^{3}$ Few scholars who master Sanskrit go on to add Syriac, or Armenian, or any other combination of fundamental languages to particular traditions. How could one, whose expertise lies elsewhere, hope to speak definitively on a subject, while relying on translations and their own dilettantish curiosities? It is my suspicion that our particular scholarly communities, Religious Studies, and its partners in History and Literature, are ill-practiced at, and perhaps ill-equipped for, crossing over traditions in the interest of interdisciplinary perspectives and compelling theories that might expand our ways of knowing. Given that the fields of History and Religion have historically relied on specializations in particular languages and time periods, any hope of transcending discipline-oriented impediments renders collaborative work imperative. This paper

(Epstein 2019).

2 I agree with Massimo Rondolino's view of hagiography as a metalinguistic category of analysis, useful for pursuing "more sophisticated understanding of religious phenomena as human expressions within given historical and cultural realities" (Rondolino 2017, p. 6). See also (Freiberger 2018, p. 5).

3 Some recent, and notable, comparative work includes: (Hawley 2018; Rondolino 2017; Cuffel et al. 2018). 
responds to this question of how a scholar might effectively traverse the high walls of one's discipline, especially in the realm of hagiology.

Hagiology is a particularly interesting locus of disciplinary interchange. Saintly figures and their stories abound in many religious traditions. The stories often approximate each other with minor changes in framing details or underlying theologies. It came as somewhat of a surprise to me after graduate school to realize that my colleagues, who had specialized in different languages and traditions, were working with saintly materials that could be considered strikingly similar to my own on a number of levels. Why had we never discussed our texts? Was there really nothing we could hope to learn from each other because the narratives were housed in different languages and cultures? Although, the movement towards area studies departments offers one possibility, it can also create competing loyalties and further artificial boundaries. I am not interested in making an argument that "religious" behavior transcends cultural boundaries in some categorizable form, but certainly there is some value in exploring the common ground and diversity that exist amidst these silos of particular religious traditions, history, and literature.

I remember well a dialogue between two leading scholars at a premiere university, who happened to study monasticism in their respective fields. Both had studied the other's tradition at some point in their scholarly journeys, and one scholar pointed out the numerous similarities between the traditions in the way monastic practice was conducted. Nodding along, the other scholar made nice, and later circled back to me to explain that there was almost nothing that could be considered similar about monasticism in the two traditions.

This highlights the historical terrain of Religious Studies and the resulting paradigms that we now seen in the academic study of comparative religions. ${ }^{4}$ The history of comparative study, and its subsequent distrust, serves to preclude us from useful paradigms of study in, and outside, our fields of interest. ${ }^{5}$ Returning to our initial question of how we push past the siloed nature of thinking in academic disciplines, I propose comparative study as the most useful academic tool when skillfully employed. A recent example from my own liberal arts college emerged when a working group, focused on assessing undergraduate composition, attempted to compare best practices for writing in various fields (Humanities, Sciences, Arts, Social-Sciences). Scholars were jarred by the variation in requirements and what that indicated about the styles of scholarship. For instance, many were surprised to realize that few Scientific articles would venture to quote a phrase from another scholar as the study of Humanities regularly does. Others found remarkable the simple notion that the date of an article is more prominent in APA style than it is in Chicago. These details tell us something about what we value as scholars and ignite our curiosities about why we value it.

What, if any, are the values of a comparative theory or methodology in the study of the saints across traditions? Does a category's meaning develop when considered outside of their regular or received context, i.e., panegyric, devotional material, compilation, theological treatise, training manual? How do we push past the siloed nature of thinking in academic disciplines and fields of study? For example, how might one's reading of a text be affected by awareness of other modes of

4 For a concise history of this tension, see Sara Ritchey's contribution to this special issue (Ritchey 2019).

5 There are exceptions, of course. One worth noting occurred between my field of late antique Christian studies and the fields of anthropology and social theory. A seminal text in the study of Christian saints, Peter Brown's 1971 article in the Journal of Roman Studies, "The Rise and Function of the Holy Man in Late Antiquity," cites in his first footnote Mary Douglas as an inspiration toward his work. Brown's later work on asceticism, The Body and Society, cites the influence of Michel Foucault in his introduction. I raise these instances because I think Brown embodies the best version of collaboration with fields of study and theories that may, at first, appear to have little impact on the late ancient world of Christianity. Peter Brown leads as a generalist as much as a specialist; his seminars regularly included a wide variety of material that, at first glance, seemed only tangentially related to the topic. In my graduate program, I was delighted to hear from a colleague of mine, studying South Asian saints, that he found Brown's work to be influential and enlightening in his own field of study. This detail is useful for framing the style of comparative studies that may prove most generative. See (Brown 1971, 2008, p. xvii). 
writing/reading/reception/function $?^{6}$ I argue that similar realizations occur when scholars of hagiography explore the worlds of saintly material outside their traditions and time periods. Perhaps most difficult in this enterprise is to allow oneself to go down the road of basic comparison, acknowledging that initial results will sometimes appear simple and uninspiring-much like that aforementioned professor anticipated. One worries, at times, that there will be scant results, barely surpassing the enthusiastic claims of, "My tradition has a saint that sounds almost identical to that!" I want to propose, however, that pushing the comparison a few different directions might yield more considerable outcomes.

In order to organize these questions into ways we might read texts in conversation and collaboration with other scholars and traditions, I offer here a nascent attempt at best practices for comparative hagiology in a conference setting.

\section{Best Practices in Comparative Hagiology}

Freiberger has insightfully argued that "Much of what is regarded as problematic about comparison in the study of religion (decontextualization, essentialization, undue generalization) should be discussed, in my view, not only in theoretical but also in methodological terms." ${ }^{17}$ Working with his open-ended and excellent methodology, this section explores how this might function in a conference panel setting, oriented toward comparative hagiology. This model represents my reworking of the incisive ideas of Sara Ritchey, Jon Keune, and Patton Burchett, who experimented in how to best organize a panel for a joint session of the 2018 AAR sponsored by the Hinduism unit, and precipitated by the Hagiographical Society's working group.

\subsection{Expand the Range of Meaning Beyond Genres}

The first aspect of comparative work, that I want to consider, is the widening scope of interpretation that is gaining momentum in some scholarly circles. ${ }^{8}$ Beginning with the notion of saints' lives as literature, it is interesting to consider how the concept of genre has worked, in the words of Sara Ritchey, to "overdetermine interpretations of sacred biography." Should all hagiography be read in the same way? Was it received in its original contexts in the ways we conceive of it today? I find this framing apparatus works in a number of western, Christian interpretive contexts. When we hear someone call something, "gospel" or "scripture" or "panegyric" or "poetry" we gain a facility with these texts. At the same time, we start to lose possibilities of interpretation and understanding. Similarly, the compilation, to use one hagiographical style, is readily embraced as another attempt at encyclopedic knowledge. ${ }^{9}$ Reading compilations as attempts at universal knowledge is certainly enlightening, but it does not encompass the possibilities that lie within these enigmatic collections. In order to start considering the potential of reading beyond particular categories, it is useful to inquire as to whether the category exists in other historical contexts. The simple act of exploring a category in a parallel world gets one thinking

6 Not limiting the saintly material to text is an important step in expanding the discussion beyond the written word, in order to include varieties of material culture. Here see Jon Keune's essay that favors the term "hagiology" over "hagiography" (Keune 2019).

7 (Freiberger 2018, p. 11).

8 I would point out a forthcoming volume, Constructed Sainthood, in Vigiliae Christianae Supplements, edited by Christa Gray (Univ. Reading) and James Corke-Webster (Kings College London), that is the outcome of a British Academy Leverhulme project. In it a series of scholars explore the various ways hagiography has been utilized by its authors and readers, and in what ways it can be investigated by contemporary scholars. My work in this volume begins with the question of whether, and how, the compilatory framework-both the impetus to compile multiple saints' lives and the subsequent reception history—grew as a uniquely advantageous style in the hands of late antique authors.

9 Similar to what Hildegard of Bingen attempted in her Physica: Liber subtilitatum diversarum naturarum creaturarum and Causae et Curae, or Hugh of Saint-Victor with his treatment of the arts in Didascalicon. Several excellent bibliographies relating to encyclopaedism are readily available online. See the "Medieval Encylopedias, Bestiaries, Lapidaries, and Herbals" entry from ARC Humanities Press; the online journal, Spicae, Cahiers de l'Atelier Vincent de Beauvais; and the Atelier Vincent de Beauvais: "Bibliographie sur les encyclopédies médiévales. See also (Hildegard 2003, 2010; Hugues de Saint-Victor 1997). 
about the category itself, and how it might benefit from further definition or critical investigation. ${ }^{10}$ What drove the author to compile, and was it the same everywhere? Whether this question is answered or not, the historian has already opened the possibility of interpretation beyond the normative methods and theories of their field.

Beginning with this framework, it is fascinating to think about the ways that we might be reading a text incongruously with its intended purpose- of course, this style of inquiry has always been the privilege of the historian. Using a brief example from my own work, I would cite the collection of John of Ephesus in the sixth-century, Byzantine context. John is championed as the Miaphysite bishop who worked closely with the Emperor Justinian (Chalcedonian) and Empress Theodora (Miaphysite). I think it is tempting to read John's work as a piece of history or theology, without paying attention to the enormously influential political terrain of his day. ${ }^{11}$ Individual lives can easily be plucked from John's work to render several different narratives of the saints in the Syrian context. Possibilities multiply as the number of included saints grows. How does a story change when it is coupled with other stories? Moreover, what might be the aims of someone engaging in the compiling process? Might a text be read against itself, or in remembrance of a movement or doctrine that it openly denounces? In all of these questions, we see the possibilities of reading texts in less constricted ways for wider fields of meaning.

Did all hagiographers intend their saintly literature to be read in the same ways? We must be missing out on some social contexts, or jokes, or literary styles and traditions that would make as little sense to us today as the choice to write a saint's life in the first place. Indeed, the entire enterprise of drafting saintly material can be foreign to the modern scholar and requires a rethinking of our own position vis-à-vis the text. In conclusion of this point, the category of "hagiography", as some static repository, is in need of continual complication. Coming together initially with an interest in expanding beyond the range of regular meanings is an ideal first step in allowing the comparative process to excel. This leads to a second aspect: How to settle on common territory.

\subsection{Begin with a Theme}

This step is the most complicated, as it ponders the question of whether and how to let go of that which got us here. I want to first cite Freiberger's assertion that the selection of the comparands prior to the act of the comparison "presupposes a prior act of comparison."12 With this in mind, it becomes important to consider the possibility that a theme, or tertium comparationis, over which the comparands might be selected and brought into conversation, could be an important first step in holding open a space that is less encumbered by predispositions and vectors of interest. This may not be possible in every field, but within the context of hagiology, it appears not only feasible but advantageous. Within the framework of hagiology, analogous themes abound, often unhindered by theologies or Sitz im Leben. ${ }^{13}$

This raises the question of the definitional problems of hagiology that Rondolino, Keune, and Ritchey explore in their papers for this volume. ${ }^{14}$ How would one know they are engaging with the same "stuff" unless agreed upon signifiers can be placed? One option, which aligns with Rondolino's "heuristic" form is to delimit by choosing particular themes that are oriented toward saintly behavior and its retelling, such as: Miraculous, holiness, otherworldliness, asceticism, and subsequent

10 See Rondolino's piece in this volume that argues hagiography functions as a heuristic device, rather than a specific genre (Rondolino 2019).

11 We might render this broader view a historically-conceived “thick description" of John's work. See (Geertz 1973).

12 (Freiberger 2018, p. 8).

3 This notion is worthy of significant further study.

14 Rondolino argues for hagiography as a "heuristic device that serves a taxonomical function for: (1) the identification of a given datum; (2) its classification within a group of similar and already known phenomena; and (3) its study and interpretation in light of the web of relationships and characteristics proper to that group" (Rondolino 2019). 
subjectivities, or monastic - and their approximate counterparts in translation..$^{15}$ Once scholars assent to these signifiers, a range of topics emerge as possibilities for the tertium comparationis: Material artifacts, comeuppance or retribution, forgiveness, healing, challenges to authority, political leaders, reception, production, promulgation, devotion, city/country, compilation, literary aspects, economics (both money and modes of exchange), social justice, death, community, politics, the author, plot, asceticism, subjectivities, love, sexuality, violence, and the heretical. ${ }^{16}$ Focusing on a single theme keeps the conversation centralized and increases the chances of attaining some depth.

The job of this first aspect is to arbitrarily narrow the field of interest to a manageable locus, based on the personal interest of the involved scholars. Given the wide variety of saintly material in any tradition, and multiplying that across disciplines, the creation of a third space, in which comparative partners can play with ideas becomes necessary. ${ }^{17}$ I would cite the recent development in the Hagiographical Society's AAR working group that has attempted to partner scholars from varying traditions in the exploration of particular themes. ${ }^{18}$ As an example: The theme for 2018 was the concept of the "miraculous." Scholars were allowed to choose a text or figure to explore from this viewpoint and formulate their own theories on the topic in their traditions and areas of expertise. One important outcome of this first step is that it limits the tendency to look for simple analogues across traditions and then orient them toward a basic tertium comparationis. Beginning with a theme, and then exploring the way that theme emerges in a context, yields richer and more complicated findings, e.g., not "My saint also levitates," but "How and why does the supernatural manifest in a given context?"

\subsection{Choose Initial Frameworks for Reading the Theme from Various Traditions}

Within the comparative group, scholars may choose different ways of thinking about the theme. As in step one (above) this can feel somewhat arbitrary as it is based on the preference of the scholar. In our 2018 panel, themes were proposed by the individual scholars: Transgressive actions reinterpreted; objects, agency, and transmission; conflicts and competition in community and teaching; and retribution and agency. Scholars identified these starting points based on their own interests and initial ways of reading, which helped other participants to think with these notions as they explored their own topics. In other words, beginning with a foreign framework, or hearing the kinds of questions different scholars apply to their sources, allows the scholar to read their own texts in new light, before even hearing others' findings. This also increases the possibility of overlapping insights. Rather than each scholar reading their material with their favorite lenses, this step gives a foreshadowing of what other ways of reading might be applied to the project.

\subsection{Share Unfinished Papers for Commentary}

When scholars are asked to share their papers before they are complete- a truly daunting practice for any scholar-the possibility of cohesion emerges. Rather than the stagnant conference paper, or edited volume with a few retro-fitted citations from other chapters to make it look cohesive, the scholar has a chance to really think about how their texts might change in the new light of other research styles and traditions. Having attended national conferences for well over a decade, I can attest to the strong tradition of failed attempts at drawing together panels with a moderator or respondent, who reads the papers a few days before they are presented. This step leaves room

15 The problem of language in translation is significant. Does miracle mean the same in translation? This is another rich field of possibility for exploration in the comparative framework. On Asceticism creating new subjectivities. See (Valantasis 2002, p. 548).

16 This list is obviously not comprehensive, but gives a sense of the variety of topics that are widely available in different traditions.

17 See Keune's argument that focusing on the basic methodologies serves to foreground "playful, creative, and open-ended conversations among the collaborators, rather than the disparities and differences that will inevitably arise when diverse specialists come together" (Keune 2019).

18 Sara Ritchey has been particularly instrumental in facilitating these dialogues. 
for early communication, pivoting in ideas, and exploration of new styles of interpretation: all the things we regularly tout as tantamount to the scholarly process, but rarely leave time for in our own conference work.

\subsection{Leave Room for Rounds of Communication}

Comparison takes time. As scholars we are accustomed to acting as the authority on a subject and what we find is often publishable and well-received as definitive. Building in the extra steps of communicating what frameworks (step 3) the scholar sees as directly applicable to their own work, as well as what new ideas were sparked by way of the initial sharing of papers is an essential step in the comparative process. This cross-fertilization can obviously take many forms such as: Commentary on each other's papers, a colloquium (if funding permits), round-robin summarization of each other's papers, a word cloud approach at prominent themes, or a short comparative paper in which one uses another scholar's methodology on their topic, or looks for points of crossover and difference, with an attempt to explain why these occur.

\subsection{Generate a Core Body of Interest}

As any scholar of hagiology will concur, one can find almost anything in the storehouse of saintly material. In order to deepen the conversation on a given topic, the comparative group needs to focus on a particular core of issues they want to further examine. A succinct way of doing this is having each participant make a "top five list" of bullet points that they see as the most promising ways forward. There will inevitably be consensus on some issues or ideas, which make for excellent nodes of connection and serve to decrease the time scholars must invest to engage with each other's ideas. What is perhaps most intriguing in this step, however, is the reflection on what areas do not overlap and why they do not. In this step, each participant should consider why certain ideas stand out as valuable points of interest in their own work, but are absent in another tradition or historical setting.

\subsection{Return to Your Work with New Perspectives}

After these initial steps of collaboration, it is very intriguing to re-encounter your initial paper with the breadth of ideas and interpretations of the theme that has been generated in the comparative work. Far from looking for consensus, or simple comparisons, the scholar is able to re-invigorate their initial ideas with the range of possibilities emerging from their collaborative partners.

\subsection{Add the Voice of an Outside Respondent}

As a final perspective, the collaborators might include the voice of an outside scholar, who could take the overarching view and discuss themes and styles that might be useful to the participants. The process of going deep in comparison on the ground will regularly benefit from a return to the overarching perspective, that can bring themes together and reinvigorate dialogue in finely tuned directions.

\section{A Few Brief Personal Observations on the Process}

Although I anticipated the final round of work to be most insightful, I was surprised to find one of the most useful aspects of this process was the initial paper writing in conversation with the others' proposed frameworks. In knowing the concepts that the other scholars would pursue on our theme, I found myself addressing the material in unique ways. Instead of quickly skimming over the preliminary narrative of my saint, I was attuned to new ways of reading. For example, I began to question whether my saint's violent retribution, the death of children from uncooperative parents, should be considered a miracle at all, and how it might have been interpreted in that community. Moreover, I began to think about the narrative in light of the framework of "competition in community" and realized my text needed far more contextual inquiry, since it only gives one side of a very 
contentious story. I could reconsider my own proclivities toward the theme of retribution in the saints and put the text in conversation with my comparative group's chosen frameworks: Concepts of agency, and transmission; transgressive actions reinterpreted; conflicts and competition in community and teaching. New insights in my own work emerged and old connections were highlighted in vivid relief.

This process awoke new, curious aspects of my own work, because I researched my saints knowing that it would be read by scholars from different traditions. I am reasonably familiar with some of the South Asian traditions and found the reading of my own texts and subsequent writing about them was imbued with a new sense of possibility and range of understanding. As a quick example, the oblation or eucharistic practice and the economy of divine power surrounding it, took on new meaning in thinking about various Hindu rites. As I read, several new interpretations emerged. I was reminded of the power of the eucharist for early Christians, who saw in it a type of direct exchange with the divine. I had never considered this power dynamic in my particular story. A colleague's exploration of interpretation of transgressive action and how they were interpreted by the community, in which it occurred, as well as later readers was particularly insightful for my own work on retribution, making me aware of a layer I had missed in my work. The collaboration moved several of us to think more deeply about what constitutes a "miracle" in our own context and beyond.

I recognize that we naturally read our texts with lenses that are most accessible and foundational to our intellectual heritage - that which our Doktormütter and -väter trained us to examine. When I pick up a text, I am immediately drawn to envisioning what it looked like on the ground, what the theological problems were, and how these get worked out socially. Although a great model, it leaves a significant swath of possible interpretive options untouched. In conversation with other traditions, we think more deeply about the possibilities of writing and reading in our own context.

I am drawn to a method of comparative work that acknowledges one's own position within the tradition and seeks to disrupt these normative readings as much as possible. If one begins with a shared theme, the inclination to look for simple similarities is quickly traversed, opening the way for sustained contemplation on the ways of reading that do not come naturally. The outcome of these is then to read alongside, and in conversation, with one's own field for wider possibilities of interpretation.

Comparative work is not easy. In order to successfully achieve an outcome that rises above simple similarities, numerous steps, additional time, and increased communication are required. There is a naturally destabilizing effect that occurs when one subjects the well-worn paths of their intellectual heritage and like-minded research communities to the scrutiny of outsiders. In effect, this project is akin to comparison of, not only texts and themes, but also the comparison of academic enclaves. What are the underlying proclivities of a field that we as scholars are reluctant to lay bare? What inherited styles might we be unaware of in our scholarship? This internal scrutiny is the most significant outcome of the comparative project.

In conclusion, the comparative paradigm serves not to find some common ground for a grand narrative about the baseline of religions, nor for finding links that prove primacy or mimicry, but rather a catalyst for seeing again one's own field with clarity, drawing on the wealth of fresh perspectives and awareness. If I may liken this to the claims of Martha Nussbaum in her early work on cosmopolitanism, we might see that we can only accurately learn about ourselves in the context of others. ${ }^{19}$ Or, in this case, we may better understand our own histories and traditions of inquiry if we can parse out our own predilections and blind-spots. The comparative project is uniquely useful in helping one to achieve this perspective. It leaves me wondering how those two scholars of monasticism might have benefited from a more open and deliberate conversation about their shared intellectual spaces.

Funding: This research received no external funding.

Conflicts of Interest: The author declares no conflict of interest.

19 (Nussbaum and Cohen 2002, pp. 11-12). 


\section{References}

Brown, Peter. 1971. The Rise and Function of the Holy Man in Late Antiquity. The Journal of Roman Studies 61: 80-101. [CrossRef]

Brown, Peter. 2008. The Body and Society: Men, Women, and Sexual Renunciation in Early Christianity. Columbia Classics in Religion. New York: Columbia University Press.

Cuffel, Alexandra, Ana Echevarría, and Georgios T. Halkias. 2018. Religious Boundaries for Sex, Gender, and Corporeality. London: Routledge.

Epstein, David. 2019. Range: Why Generalists Triumph in a Specialized World. New York: Riverhead Books.

Freiberger, Oliver. 2018. Elements of a Comparative Methodology in the Study of Religion. Religions 9: 38. [CrossRef]

Geertz, Clifford. 1973. The Interpretation of Cultures. New York: Basic Books.

Hawley, John Stratton. 2018. The Four Churches of the Reformation. Modern Asian Studies 52: 1457-85. [CrossRef] Hildegard, Saint. 2003. Beate Hildegardis Cause et Cure. Berlin: Akademie Verlag.

Hildegard, Saint. 2010. Physica: Liber Subtilitatum Diversarum Naturarum Creaturarum: Textkritische Ausgabe. Berlin: De Gruyter.

Hugues de Saint-Victor. 1997. Didascalicon de Studio Legendi = Studienbuch. New York: Herder.

Keune, Jon. 2019. Comparative vs. Hagiology. Two Variant Approaches to the Field. Religions 10: 575.

Nussbaum, Martha, and Joshua Cohen. 2002. For Love of Country? Boston: Beacon Press.

Ritchey, Sara. 2019. Dialogue and Destabilization: An Index for Comparative Global Exemplarity. Religions 10. Forthcoming. [CrossRef]

Rondolino, Massimo A. 2017. Cross-Cultural Perspectives on Hagiographical Strategies: A Comparative Study of the Standard Lives of St. Francis and Milarepa. London: Routledge, Taylor \& Francis Group.

Rondolino, Massimo A. 2019. Some Foundational Considerations on Taxonomy: A Case for Hagiography. Religions 10: 538. [CrossRef]

Valantasis, Richard. 2002. A Theory of the Social Function of Asceticism. In Asceticism. Edited by Richard Valantasis and Vincent L. Wimbush. Oxford: Oxford University Press, pp. 544-52.

(C) 2019 by the author. Licensee MDPI, Basel, Switzerland. This article is an open access article distributed under the terms and conditions of the Creative Commons Attribution (CC BY) license (http://creativecommons.org/licenses/by/4.0/). 